\title{
Conservative Surgical Approach to Pleomorphic Adenoma in Parotid Gland: Case Report
}

\section{Abordagem Cirúrgica Conservadora de Adenoma Pleomórfico em Glândula Parótida: Relato de Caso}

\author{
Davisson Alves Pereira*ab; Eduvaldo Campos Soares Junior ${ }^{\text {ab }}$; Mariana da Silva Bonatto ${ }^{\text {; }}$ Kallyne Munik Souza \\ Morato $^{\mathrm{b}}$; André Luis Fernandes da Silva ${ }^{\mathrm{b}}$
}

${ }^{a}$ Federal Universidade of Uberlândia, Stricto Sensu Post-Graduate Program in Dentistry. MG, Brazil. bUniversity of Cuiabá, Residence Program in Surgery and Buccomaxillofacial Traumatology. MT, Brazil.

*E-mail: davisoncaneda@hotmail.com

Recebido em: 31/01/2020

Aprovado em: 04/05/2020

\begin{abstract}
Pleomorphic adenoma is a benign neoplasm of the salivary glands that affects most frequently females in the fourth and sixth decade of life. As it is usually an asymptomatic lesion, it is diagnosed upon routine physical examination. Treatment consists of surgical removal with partial or total involvement of the parotid gland. Conservative enucleation is the least invasive surgical option for this type of lesion. The present work aimed at reporting a case of pleomorphic adenoma of the parotid gland with eight years of evolution. The tumor was treated conservatively. Patient has been followed for sixth months, and no sensory alterations, fistulae, clinical signs of recurrence, nor any other alterations have been observed so far. Due to the lesion benign nature, an evolution with favorable prognosis is expected.
\end{abstract}

Keywords: Adenoma. Neoplasms. Salivary Glands.

\section{Resumo}

O Adenoma pleomórfico é uma neoplasia benigna de glândulas salivares, que acomete com maior frequência pessoas do sexo feminino entre a quarta e sexta década de vida. Por se tratar de uma lesão muitas vezes assintomática, geralmente é descoberta através do exame físico de rotina. O seu tratamento consiste em remoção cirúrgica podendo envolver ou não a glândula parótida de maneira parcial ou total. A enucleação conservadora é a modalidade cirúrgica menos invasiva para este tipo de lesão. O presente trabalho tem por objetivo relatar um caso de adenoma pleomórfico em glândula parótida com oito anos de evolução. O tumor foi tratado de maneira conservadora. A paciente está sendo acompanhada há 6 meses e não foram observados até momento alterações sensoriais, fistulas, indícios clínicos de recidiva ou qualquer outra alteração. Devido ao caráter benigno da lesão, espera-se evolução com prognóstico favorável.

Palavras-chave: Adenoma. Neoplasias. Glândulas Salivares.

\section{Introduction}

Salivary glands tumors (SGT) play a prominent role in human neoplasms, although uncommon, comprise an important area of oral pathology and represent one of the most interesting and challenging tumor groups in the head and neck region $^{1,2}$. SGTs have an annual incidence in the west ofrom 2.5 to 3.0 cases for every 100.000 persons $^{3-7}$.

Within this group, pleomorphic adenoma (PA), the most common benign neoplasm of the major salivary glands (GSMA) and minor ones (GSMe) stand out ${ }^{3,8,9}$. This lesion is described as a slow evolution neoplasm, well delimited, painless, apparently encapsulated, that rarely exceeds 5 $\mathrm{cm}$ in its largest diameter ${ }^{3,5,10}$. The PA capacity to undergo recurrences and malignant transformation has been reported by the literature, especially in cases where there has been incomplete surgical excision, multiple local recurrences and in tumors that have remained for long periods without diagnosis and treatment ${ }^{11-15}$.

Although the clinical and histological aspects of this neoplasia are well known, its etiology and pathogenesis remain uncertain $^{4}$. However, it is known that in more than $70 \%$ of the cases there is an association with abnormal karyotypes, involving a locus of the PLAG1 gene ( Pleomorphic adenoma gene 1 ). Recently, new genes that may be involved in tumor formation have been identified ${ }^{16}$. In addition, there are evidences that exposure to UV (ultraviolet) rays increases the risk of developing it $^{3}$.

The treatment of choice for this neoplasia consists of complete surgical excision ${ }^{17}$. In the parotid gland, when the tumor is located in the superficial lobe, it may be necessary to perform the superficial parotidectomy preserving the facial nerve. On the other hand, when the tumor is located in the deep lobe, total parotidectomy is recommended $d^{7,14,18,19}$.

The objective of this study is to report a case of pleomorphic adenoma in the parotid gland. The lesion was surgically treated conservatively and is found to be 6 months of follow-up without showing signs of recurrence.

\section{Case Report}

Patient M.L., female, 66 years old, brown, housemaidc, appeared at the outpatient clinic of the Buccomaxillofacial 
Surgery and Traumatology Service of General Hospital of Cuiabá - MT, presenting a volumetric increase on the left side face, with evolution time of approximately 8 years and referring to mild discomfort to palpation.

In the anamnesis, she reported having controlled systemic arterial hypertension (SAH) with the use of Captopril ${ }^{\circledR} 25 \mathrm{mg}$ and Hydrochlorothiazide 25mg, both ingested once a day. Upon extra-oral physical examination, a mobile volumetric increase was observed in the left parotid gland region of approximately $35 \mathrm{~mm}$ in its largest diameter,sessile basis, delimited, of hardened and painful consistency to palpation (Figure 1a). No significant changes were observed in the intraoral evaluation (Figure 1b).

Figure 1 - Extra and intra-oral physical examination . (1a) Delimitation of the volumetric increase in the left parotid gland region; (1b) intraoral view demonstrating integrity of the remaining mucous membranes and dental elements

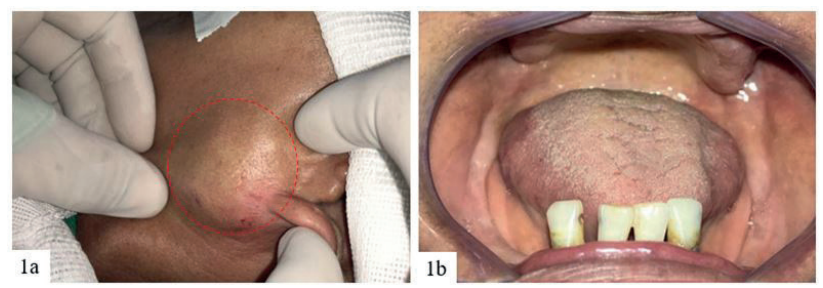

Source: The authors

Computed tomography revealed a well-delimited, circumscribed hyperdense lesion, approximately $35 \mathrm{~mm}$ in its largest diameter, irregular surface, located superficially in the left parotid gland. After clinical evaluation and complementary tests, the diagnostic hypothesis of pleomorphic adenoma was raised.

The surgical planning proposed consisted of excisional biopsy for lesion enucleation. The procedure was performed in a surgical center under general anesthesia balanced by nasotracheal intubation. The access of choice was the submandibular one located in the cervical region just below the lesion (Figure $2 \mathrm{a}$ and $2 \mathrm{~b}$ ). The divulsion continued until the capsule of the lesion, individualizing it in order to release it from all the adherences (Figure 2c). The manipulation and clamping of the lesion caused the leakage of whitish staining viscous content (figure $2 \mathrm{~d}$ and $2 \mathrm{e}$ ). After dissection of the lesion and its excision, hemostasis and copious irrigation of the surgical wound were performed (Figure 2f). The suture was performed by tissue planes, with 4-0 polyglycolic acid absorbable thread in the internal planes and the suture of the skin with nylon 5-0 (Figure $2 \mathrm{~g}$ and $2 \mathrm{~h}$ ).
Figure 2 - Surgical procedure steps. (2a and 2b) Conservative submandibular access; (2c) Lesional capsule disclosure; (2d and 2e) Lesion individualization and clamping; (2f) Surgical bed after lesion removal;(2g); Internal flat suture; (2h) Skin sutures
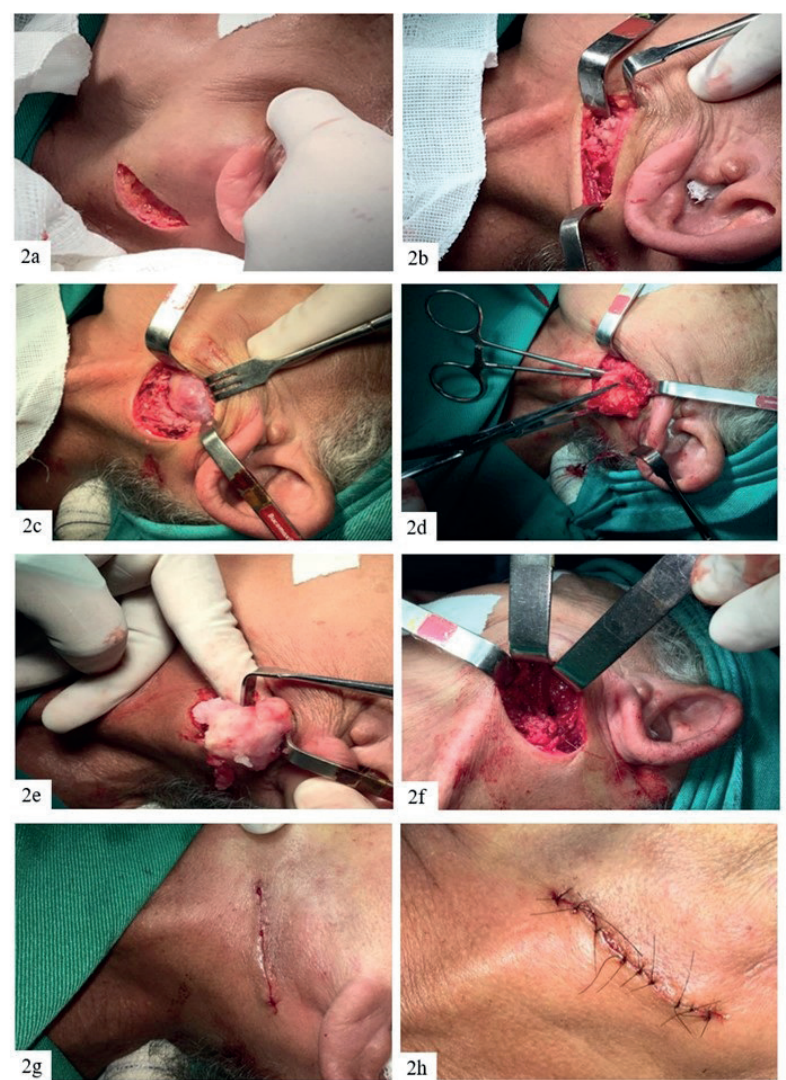

Source: The authors.

Lesion analysis showed the presence of capsule with whitish and viscous content inside (Figure 3a), size of approximately $35 \mathrm{~mm}$, petreous consistency and rounded shape (Figure 3b). The lesion storage was performed in $10 \%$ formaldehyde solution and the piece was referred for anatomo-histopathological evaluation.

Figure 3 - Lesion after its removal from surgical bed. (3a) whitish lesion after removal of the surgical bed; (3b) approximate size of $3.5 \mathrm{~cm}$ in its largest diameter
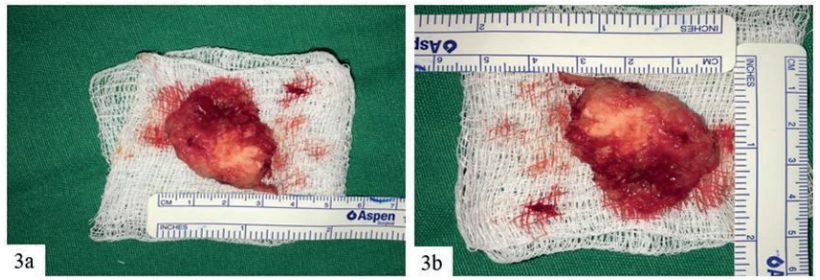

Source: The authors.

In the seven-day postoperative period, the skin sutures were removed, a good scar aspect was observed without evidence of dehiscence, cardinal signs of inflammation or infection (Figure 4a and 4b). The mimicry motricity was preserved and the patient did not present complaints (Figure $4 \mathrm{c}$ and $4 \mathrm{~d})$. 
Figure 4 - Evolution of 7 days of surgical procedure process. (4a) 7-day postoperative period, skin sutures with good scar aspect are noted; (4b) In evidence, suture area with excellent co-opted area and absence of signs of inflammation; (4c and 4d) Motor movement of preserved mimicry is noted
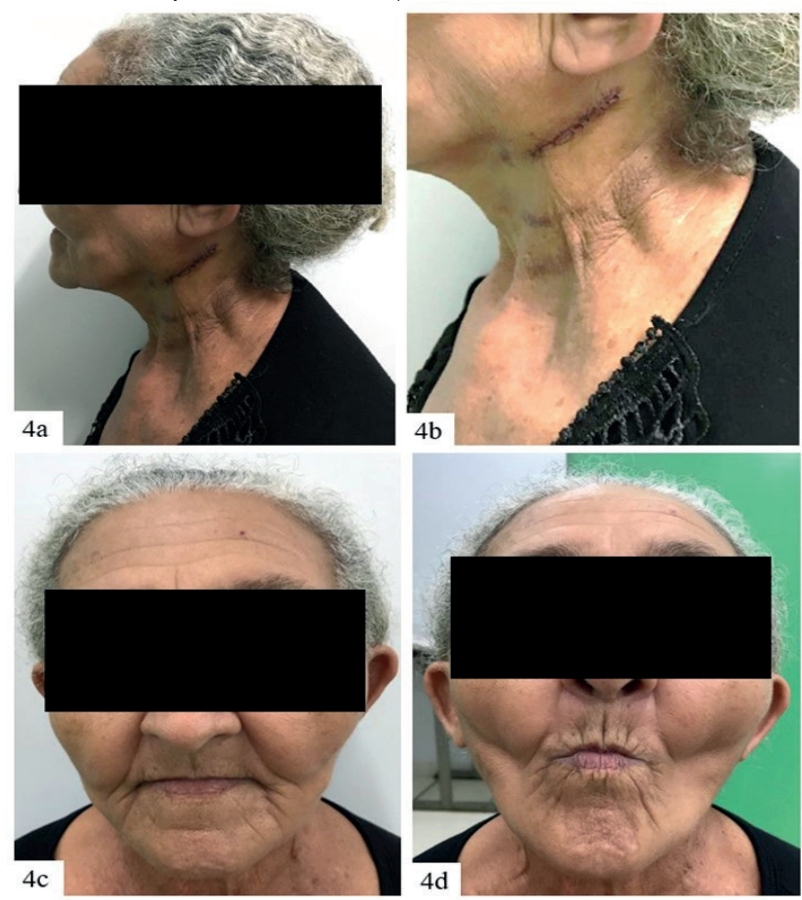

Source: The authors.

The histopathological report confirmed the diagnostic hypothesis of pleomorphic adenoma (Figure 5a and 5b).

Figure 5 - Confirmatory histopathological examination of pleomorphic adenoma. (5a) Histological sections reveal a fragment of ectodermal neoplasm originating from the salivary gland represented almost exclusively by chondroid tissue; (5b) The histological sections reveal a fragment of ectodermal neoplasm originating from salivary gland, consisting of solid parenchyma permeated by a few small ductiform structures composed of two cellular layers interpreted as being: neoplastic ductal epithelial cell and neoplastic myoepithelial cell. Extensive chondroid areas are also observed. The neoplastic stroma is formed by fibrous connective tissue

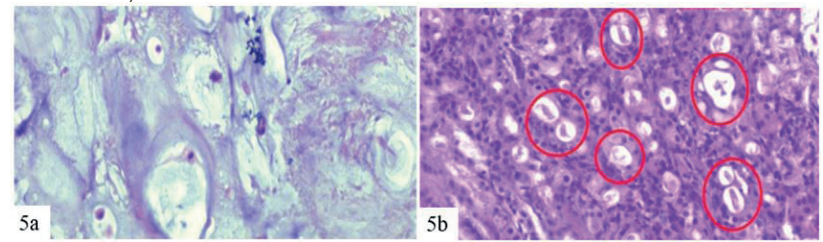

Source: The authors.

Figure 6 - Patient after six months of post-operative period.

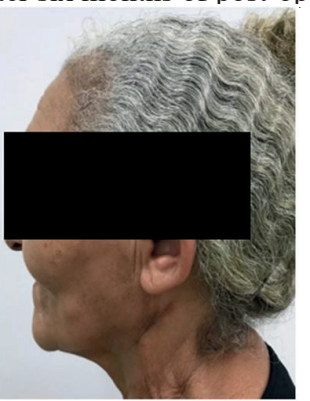

Source: The authors
In the image, there were no signs of recurrence at the operated site.

\subsection{Discussion}

Pleomorphic adenoma is the most common benign neoplasm affecting the parotid gland ${ }^{2,15}$. It presents a predilection for the female gender in a variable proportion found in the literature, with an average of around 1,5:1, and although it can be found in all ages, it occurs more frequently from $4^{\text {th }}$ to $6^{\text {th }}$ decade of life ${ }^{6,9,20}$. The clinical case described in this study corroborates the epidemiological profile of the patients described in the literature.

In a retrospective clinical study of 68 patients operated with diagnosis of pleomorphic adenoma of parotid gland, the authors observed a higher frequency of pleomorphic adenoma in the left parotid gland, $61.5 \%$ of the cases, with a ratio of 1.6:1 when compared to the right side. The clinical case reported also presents location on the left side, however, in the literature there is currently no consensus regarding the side of involvement of these lesions, therefore, requiring further clarification regarding this aspect in future studies ${ }^{9}$

Although salivary glands are considered by some authors to be relatively simple organs, the same cannot be asserted for neoplasms that affect them, mainly due to their rich histological variety ${ }^{21}$. The PA also called "mixed tumor" due to its histological diversity is the most frequent benign salivary gland neoplasia in humans. In essence, they are tumors derived from myoepithelium, with both epithelial and mesenchymal differentiation ${ }^{3,4}$.

Due to the fact that PA is a slow and asymptomatic growth lesion, it often leads to late demand for medical care and diagnosis of lesion ${ }^{5,6}$. The great majority (90\%) of pleomorphic adenomas affect the gland superficial lobe, being $80 \%$ in its lower portion ${ }^{22}$. Facial motor involvement is not common in cases of pleomorphic adenoma of parotid gland, although it may occur by compression or stretching of the nerve by voluminous tumors ${ }^{23}$.

Image exams, although not essential, are extremely important, since they help to determine the location, extent and shape of the lesion, contributing to the diagnosis complementation and to surgical planning. Salivary glands pathologies present several image characteristics and the examination to be chosen depends on some factors, such as the lesion clinical presentation, consistency, size and location $9,11,24$.

Among the most widely used, magnetic resonance imaging (MRI) is ultrasound (USG) and computed tomography (CT), usually indicated for support in the diagnosis of soft and bone tissue lesions. The ultrasound examination assists in the assessment of lesion consistency ${ }^{11,24}$, while the magnetic resonance image is particularly useful to demonstrate the tumor and surrounding tissues interface ${ }^{15}$. Pleomorphic adenoma often has a characteristic appearance in magnetic resonance images, presenting homogeneous hyperintensity in T2, well- 
circumscribed borders and solid contrast enhancement ${ }^{24-26}$.

As for the treatment form, the lesions located in the superficial lobe of the parotid gland are better treated through superficial parotidectomy, with identification and preservation of the facial nerve. On the other hand, lesions located in the deep lobe, total parotidectomy is usually necessary, if possible, with the facial nerve preservation. Local enucleation should be avoided, as the neoplasm may not be completely removed or the capsule may be violated, resulting in cells remaining in the tumor bed. Conservative enucleation can result in recurrence, making it difficult to manage these cases due to the multifocal dissemination in the primary bed ${ }^{11,12}$.

The exact causes of recurrence of pleomorphic adenoma remained contradictory. The widely accepted hypothesis is the subtotal removal of the tumor due to inadequate surgery, while the characteristics of the tumor capsule or other histological aspects are rarely examined ${ }^{12,27}$. Recurrence rates range from zero to $14 \%$ when the surgical procedure is extracapsular dissection and the main cause for this recurrence is the incomplete surgical resection of the pleomorphic adenoma capsule, due to partial exposure or rupture in the trans operative period $^{14,27,28}$.

Investigating the recurrence rate of pleomorphic adenoma in the evaluation of 47 patients with at least one episode of tumor recurrence, 41 cases were in parotid gland. They reached the conclusion that primary tumor surgery included tumor removal in only $36 \%$ of cases. Despite the surgical method, all surgical techniques for removing the pleomorphic adenoma of the superficial parotid expose the tumor capsule focally. The study was unable to determine tumor effusion after rupture of the primary tumor capsule, and is only known in some cases. Rupture of the primary tumor capsule and tumor effusion are strongly associated with recurrence. However, the authors found that rupture of a capsule does not always lead to recurrence and there are several reports that did not show association of tumor cells seeding with recurrences ${ }^{13,28,29}$.

Advanced reasons for the pleomorphic adenoma recurrencecan be grouped into pathological (capsule thickness, lack of capsule, pseudopod, satellite nodules) and related to surgery (tumor rupture, tumor content spill, insufficient resection margins due to nervous branches, inadequate excision related to the type of surgery). The authors found that recurrence seems to be increased in the subtype of mixed pleomorphic adenoma in which the capsule is often thinner and incomplete. Surgical variables related to recurrence include positive margins and tumor shedding, as already described by other authors. Nevertheless, the primary treatment of pleomorphic adenoma should be carefully planned, performed and centered on the lesion complete removal ${ }^{13,17,18,27,28}$.

The most common complication in the treatment of parotid pleomorphic adenoma is facial nerve involvement. In the present case, there was no functional impairment of the nerve, probably due to the technique used, extra-capsular dissection, which has lower morbidity to the nerve in question. According to Tiago et al. ${ }^{9}$, facial nerve paresis is 2.3 times greater when total parotidectomy is performed, when compared to superficial parotidectomy. In addition to facial nerve involvement, another complication that can be found is Frey's Syndrome, which is clinically presented with sweating and erythema in the parotid region, caused by interruption of parasympathetic post-ganglional fibers of the glossopharyngeal nerve that travel through the auriculotemporal nerve that infuses the parotid region ${ }^{10,19,28}$.

Although this is a benign lesion, with low recurrence rate and malignant transformation ${ }^{15}$ periodic follow-up is important for a minimum period of five years. Currently, the patient is in six months postoperative period, with no signs of recurrence.

\section{Conclusion}

Although this is a benign tumor, the previous diagnosis and treatment of pleomorphic adenoma is important, because when treated early, it has a favorable prognosis and a lower chance of recurrence. Although the possibility of recurrence is low, the patient should be monitored and evaluated periodically for at least five years. The patient of the described clinical case is in a six-month postoperative period with good evolution, with no sign of recurrence. Therefore, it can be concluded that the treatment so far is efficient and effective.

\section{References}

1. Sarmento DJS, Morais MLSA, Costa ALL, Silveira ÉJD. Minor intraoral salivary gland tumors: a clinical-pathological study. Einstein (Sao Paulo) 2016;14(4):508-12. doi: https:// doi.org/10.1590/s1679-45082016ao3749.

2. Araya J, Martinez R, Niklander S, Marshall M, Esguep A. Incidence and prevalence of salivary gland tumours in Valparaiso, Chile. Med Oral Patol Oral Cir Bucal 2015;20(5):e532-9. doi: https://dx.doi. org/10.4317\%2Fmedoral.20337

3. Khan MN, Raza SS, Hussain Zaidi SA, Haq IU, Hussain AK, Nadeem MD, et al. Pleomorphic adenoma of minor salivary glands. J Ayub Med Coll Abbottabad 2016;28(3):620-2.

4. Lopes MLD de S, Barroso KMA, Henriques ÁCG, dos Santos JN, Martins MD, de Souza LB. Pleomorphic adenomas of the salivary glands: retrospective multicentric study of 130 cases with emphasis on histopathological features. Eur Arch OtoRhino-Laryngology 2017;274(1):543-51. doi: http://dx.doi. org/10.1007/s00405-016-4253-5

5. Espinosa CA, Fernández-Valle Á, Lequerica-Fernández $\mathrm{P}$, Villalaín L, Vicente JC. Clinicopathologic and surgical study of pleomorphic adenoma of the parotid gland: analysis of risk factors for recurrence and facial nerve dysfunction. $\mathrm{J}$ Oral Maxillofac Surg 2018;76(2):347-54. doi: http://dx.doi. org/10.1016/j.joms.2017.07.171

6. Takita H, Takeshita T, Shimono T, Tanaka H, Iguchi H, Hashimoto $\mathrm{S}$, et al. Cystic lesions of the parotid gland: radiologic-pathologic correlation according to the latest World Health Organization 2017 Classification of Head and Neck Tumours. Jpn J Radiol 2017;35(11):629-47. doi: https:// doi.org/10.1007/s11604-017-0678-Z

7. Speight PM, Barrett AW. Salivary gland tumours. Oral 
Dis 2002;8(5):229-40. doi: https://doi.org/10.1034/j.16010825.2002.02870.x

8. Sousa R, Santos M, Oliveira J, Mendonça V, Alves P, Pereira J. Adenoma Pleomórfico em glândula submandibular: relato de caso e uma revisão dos achados atuais. Rev Cir Traumatol Buco-maxilo-facial 2013;13(2):9-14.

9. Tiago RSL, Araújo Castro G, Da Costa Ricardo LA, Borghi Bühler R, Fava AS. Adenoma pleomórfico de parótida: Aspectos clínicos, diagnósticos e terapêuticos. Rev Bras Otorrinolaringol 2003;69(4):485-9. doi: https://doi. org/10.1590/S0034-72992003000400008

10. Bonavolontà P, Dell'Aversana Orabona G, Maglitto F, Abbate V, Committeri U, Salzano G, et al. Postoperative complications after removal of pleomorphic adenoma from the parotid gland: A long-term follow up of 297 patients from 2002 to 2016 and a review of publications. Bras J Oral Maxillofac Surg 2019;57(10):998-1002. doi: https://doi. org/10.1016/j.bjoms.2019.08.008

11. Dombrowski ND, Wolter NE, Irace AL, Cunningham MJ, Vargas SO, Perez-Atayde AR, et al. Pleomorphic adenoma of the head and neck in children: presentation and management. Laryngoscope 2019;129(11):2603-9. doi: https://doi org/10.1002/lary.27590.

12. Kanatas A, Ho MWS, Mücke T. Current thinking about the management of recurrent pleomorphic adenoma of the parotid: a structured review. $\mathrm{Br} \mathrm{J}$ Oral Maxillofac Surg 2018;56(4):243-8. doi: https://doi.org/10.1016/j. bjoms.2018.01.021

13. Witt RL, Eisele DW, Morton RP, Nicolai P, Poorten V Vander, Zbären P. Etiology and management of recurrent parotid pleomorphic adenoma. Laryngoscope 2015;125(4):888-93. doi: https://doi.org/10.1002/lary.24964

14. Abu-Ghanem Y, Mizrachi A, Popovtzer A, Abu-Ghanem N, Feinmesser R. Recurrent pleomorphic adenoma of the parotid gland: Institutional experience and review of the literature. J Surg Oncol 2016;114(6):714-8. doi: https://doi.org/10.1002/ jso. 24392

15. Seok J, Hyun SJ, Jeong WJ, Ahn SH, Kim H, Jung YH. The Difference in the Clinical Features Between Carcinoma ex Pleomorphic Adenoma and Pleomorphic Adenoma. Ear, Nose Throat J 2019;98(8):504-9. doi: https://doi. org/10.1177\%2F0145561319855376

16. Choi JS, Cho BH, Kim HJ, Kim YM, Jang JH. Identification of new genes of pleomorphic adenoma. Med 2019;98(51). doi: https://dx.doi.org/10.1097\%2FMD.0000000000018468

17. Robertson BF, Robertson GA, Shoaib T, Soutar DS, Morley S, Robertson AG. Pleomorphic adenomas: Post-operative radiotherapy is unnecessary following primary incomplete excision: a retrospective review. J Plast Reconstr Aesthetic Surg 2014;67(12):e297-302. doi: http://dx.doi.org/10.1016/j. bjps.2014.09.030
18. Bradley PJ. The recurrent pleomorphic adenoma conundrum. Curr Opin Otolaryngol Head Neck Surg. 2018;26(2):134-41. doi: https://doi.org/10.1097/MOO.0000000000000435

19. Infante-Cossio P, Gonzalez-Cardero E, Garcia-Perla-Garcia A, Montes-Latorre E, Gutierrez-Perez JL, Prats-Golczer VE. Complications after superficial parotidectomy for pleomorphic adenoma. Med Oral Patol Oral Cir Bucal 2018;23(4):e48592. doi: https://dx.doi.org/10.4317\%2Fmedoral.22386

20. Calvo-Henriquez CE, Telmo-Mella A, Dios-Loureiro C, Martín-Martín C. Adenoma pleomorfo parotídeo gigante. Acta Otorrinolaringol Esp 2016;67(6):e40-1. doi: http:// dx.doi.org/10.1016/j.otorri.2015.12.001

21. Hellquist H, Skalova A. Histopathology of the salivary glands. Histopathology of the salivary glands. Germany: Springer; 2014.

22. Ogawa AI, Takemoto LE, Navarro PDL, Heshiki RE. Neoplasias de glândulas salivares salivary glands neoplasms. Int Arch Otorhinolaryngol 2008;409-18.

23. Jain S, Hasan S, Vyas N, Shah N, Dalal S. Pleomorphic adenoma of the parotid gland: report of a case with review of literature. Ethiop J Health Sci 2015;25(2):189-94. doi: https:// doi.org/10.4314/ejhs.v25i2.13

24. Kato H, Kawaguchi M, Ando T, Mizuta K, Aoki M, Matsuo M. Pleomorphic adenoma of salivary glands: common and uncommon CT and MR imaging features. Jpn J Radiol 2018;36(8):463-71. doi: https://doi.org/10.1007/s11604-018$0747-y$

25. Zaghi S, Hendizadeh L, Hung T, Farahvar S, Abemayor E, Sepahdari AR. MRI criteria for the diagnosis of pleomorphic adenoma: A validation study. Am J Otolaryngol- Head Neck Med Surg 2014;35(6):713-8. doi: http://dx.doi.org/10.1016/j. amjoto.2014.07.013

26. Heaton CM, Chazen JL, Van Zante A, Glastonbury CM, Kezirian EJ, Eisele DW. Pleomorphic adenoma of the major salivary glands: Diagnostic utility of FNAB and MRI. Vol. 123, Laryngoscope 2013:3056-60. doi: https://doi. org/10.1002/lary.24247

27. Dulguerov P, Todic J, Pusztaszeri M, Alotaibi NH. Why do parotid pleomorphic adenomas recur? a systematic review of pathological and surgical variables. Front Surg 2017;4:1-8. doi: https://doi.org/10.3389/fsurg.2017.00026

28. Kuriyama T, Kawata R, Higashino M, Nishikawa S, Inui $\mathrm{T}$, Terada $\mathrm{T}$, et al. Recurrent benign pleomorphic adenoma of the parotid gland: facial nerve identification and risk factors for facial nerve paralysis at re-operation. Auris Nasus Larynx 2019;46(5):779-84. doi: https://doi.org/10.1016/j. anl.2019.02.010

29. Aro K, Valle J, Tarkkanen J, Mäkitie A, Atula T. Repeatedly recurring pleomorphic adenoma: a therapeutic challenge. Acta Otorhinolaryngol Ital 2019;39(3):156-61. doi: https:// dx.doi.org/10.14639\%2F0392-100X-2307 